\title{
Short communication: A decrease in diameter of milk fat globules accompanies milk fat depression induced by conjugated linoleic acid supplementation in lactating dairy cows
}

\author{
Z. Y. Xing, ${ }^{1}$ M. L. Zhang, ${ }^{1}$ Y. Y. Wang, ${ }^{1}$ G. Y. Yang, ${ }^{1}$ L. Q. Han, ${ }^{1 *}$ and J. J. Loor ${ }^{2 *} \oplus$ \\ ${ }^{1}$ College of Animal Science and Veterinary Medicine, Henan Agricultural University, Zhengzhou 450002, P. R. China \\ ${ }^{2}$ Department of Animal Sciences and Division of Nutritional Sciences, University of Illinois, Urbana 61801
}

\begin{abstract}
Milk fat is secreted from the mammary gland in the form of milk fat globules (MFG). Although milk fat depression has been studied since the beginning of the last century, the extent to which this phenomenon alters MFG synthesis is not fully understood. The aim of this study was to evaluate the effect of conjugated linoleic acid (CLA) on the size and distribution of MFG during milk fat depression in dairy cows. Twelve Holstein cows in mid lactation $(145 \pm 31 \mathrm{~d}$ in milk, $583 \pm$ $34.6 \mathrm{~kg}$ of body weight, and $27.2 \pm 2.4 \mathrm{~kg}$ of milk/d) were randomly assigned to a control diet or control plus Ca-protected CLA at $15 \mathrm{~g} / \mathrm{kg}$ of dry matter for a 6 -d period. The average diameter and particle size distribution of MFG were measured using a Mastersizer 3000 laser particle size analyzer (Malvern Instruments Ltd., Malvern, UK). Feeding CLA did not affect dry matter intake $(16.2 \pm 0.4 \mathrm{~kg} / \mathrm{d})$, milk production $(28.4 \pm 0.4$ $\mathrm{kg} / \mathrm{d}$ ), milk protein, or lactose, but it decreased milk fat content (3.46 vs. $2.52 \%$ ). In addition, surface arearelated mean diameter of fat globules in cows fed CLA was lower compared with controls (3.02 vs. $3.45 \mu \mathrm{m})$. The percentage of large fat globules decreased and that of small fat globules increased in response to CLA. Overall, the data suggest that the milk fat depression induced by CLA is accompanied by a decrease in average diameter of MFG.
\end{abstract}

Key words: lactation, lipid droplet, fatty acids, nutrition

\section{Short Communication}

Milk fat depression (MFD) is a syndrome characterized by a reduction of milk fat content (Bauman and Griinari, 2000) often caused by feeding high-grain diets alone or in combination with vegetable or fish oil (Bau-

Received November 4, 2019.

Accepted January 9, 2020.

*Corresponding authors: qlhan2001@126.com and jloor@illinois.edu man and Griinari, 2003; Bichi et al., 2013). Although many theories have been proposed to explain MFD, the bulk of available in vivo data to date provides strong support for the trans fatty acid theory as major cause of MFD (Bionaz and Loor, 2008). This theory states that trans-10,cis-12 CLA (an intermediate of ruminal biohydrogenation; Loor et al., 2002) directly inhibits mammary synthesis of milk fat through direct effects on lipogenic enzymes (Bauman et al., 2008). Since 2000 , numerous studies have confirmed the negative effect of CLA on the synthesis of milk fat (Baumgard et al., 2000; Loor and Herbein, 2003; Viswanadha et al., 2003; Harvatine et al., 2018).

Milk fat is secreted from mammary cells as milk fat globules (MFG), unique structures composed mainly of a triacylglycerol core surrounded by a lipid bilayer membrane similar to the apical membrane of mammary epithelial cells. The diameter of MFG in secreted milk varies depending on breed (Michalski et al., 2005), genetics (Argov-Argaman et al., 2013), lactation stage (Mesilati-Stahy and Argov-Argaman, 2014), and diet (Lopez et al., 2008). For instance, diets with different concentrate-to-forage ratios reduced MFG diameter of milk accompanied by decreased milk fat (Argov-Argaman et al., 2014). Therefore, mechanisms controlling MFG size are also plausibly a component of MFD.

We hypothesized that reduction of milk fat in response to feeding CLA is associated with altered MFG size. We used a rumen-protected product rich in trans10,cis-12 CLA (Han et al., 2012) to induce MFD and measured MFG size using a laser particle size analyzer.

All procedures performed in studies involving animals were in accordance with the ethical standards of the Animal Care Committee of Henan Agricultural University. Twelve multiparous Holstein cows $(145 \pm 31$ DIM, $583 \pm 34.6 \mathrm{~kg}$ of BW, $27.2 \pm 2.4 \mathrm{~kg}$ of milk/d) were randomly divided to receive either a control basal diet or the control plus Ca-protected CLA at $15 \mathrm{~g} / \mathrm{kg}$ of DM (Qingdao Auhai Biotech Co. Ltd., Qingdao, China). All cows were adapted to the respective diets for $3 \mathrm{~d}$ followed by $6 \mathrm{~d}$ of sampling. Rations were formulated 
to meet the cows' predicted nutrient requirements according to the National Research Council (NRC, 2001). Ingredients and chemical composition of the diets are reported in Supplemental Table S1 (https://doi.org/ 10.3168/jds.2019-17845). The commercial rumen-protected CLA contained similar amounts of cis-9,trans-11 and trans-10,cis-12 isomers (Supplemental Table S2; https://doi.org/10.3168/jds.2019-17845). Cows were housed in a naturally ventilated barn, fed individually, and milked 3 times daily at 0600, 1400, and $2000 \mathrm{~h}$. They had ad libitum access to their respective diets as a TMR after each milking. Feed offered and refused was measured daily for each cow and recorded through the experimental period to calculate DM intake. Milk yield was recorded daily. To shorten the interval between sampling and analysis of MFG, milk samples were taken at the $1400 \mathrm{~h}$ milking. Milk samples were divided into 2 samples; one sample was sent to Henan DHI Testing Center to analyze milk fat, milk protein, and milk lactose concentrations using infrared spectrophotometry (Foss 120 Milko-Scan, Foss Electric, Hillerød, Denmark). The second sample was processed immediately to measure diameter and size distribution of MFG using a Mastersizer 3000 laser particle size analyzer (Malvern Instruments Ltd., Malvern, UK).

Based on the Mastersizer 3000 operating instructions, the parameter of refractive index was set at 1.560 with stirrer speed at 2,000 rpm. In preliminary experiments, we found that adding EDTA to dissociate casein micelles $(\sim 150 \mathrm{~nm})$ was unnecessary. A total of 400 $\mathrm{mL}$ of water was added to a beaker. After measuring background, $1 \mathrm{~mL}$ of a pure milk sample was added to the beaker. The system automatically measured MFG parameters 3 times and calculated an average value. The values obtained for each sample were analyzed using Mastersizer software, which yielded volume-re- lated equivalent diameter $\left(\mathbf{D}_{[4,3]}\right)$, surface area-related equivalent diameter $\left(\mathbf{D}_{[3,2]}\right)$, a particle size distribution diagram, and a table showing the percentage of size distribution.

Milk yield, milk composition and yield, and MFG diameter and distribution were all analyzed using the general linear model (GLM) and SPSS 25 software (SPSS/IBM Corp., Chicago, IL) for a full factorial model with repeated measures. The model contained time $(1,2,3,4,5$, and $6 \mathrm{~d}$ ), treatment (control and CLA), and time $\times$ treatment interactions. Significant difference was declared as $P<0.05$, and $0.05 \leq P \leq$ 0.10 was defined as statistical trends.

No time effect $(P>0.05)$ or differences between treatments $(P>0.05)$ were observed for cow DMI, milk yield, milk protein and yield, or milk lactose and yield (Table 1). Supplementation with CLA led to a significant reduction of milk fat and yield $(P<0.01)$. Most research investigating CLA effects on milk composition has consistently demonstrated that the inhibitory effects are specific to milk fat; other components and milk yield are generally unaffected (Baumgard et al., 2001; Perfield et al., 2002; Viswanadha et al., 2003), which is consistent with results from the present study.

The size distribution graph in Figure 1 clearly shows that the peak of particle distribution gradually shifted from large to small diameter with time of CLA feeding. The size of MFG across mammalian species can vary from $200 \mathrm{~nm}$ to over $15 \mu \mathrm{m}$ (Argov et al., 2008). We detected MFG sizes ranging mainly from 1.0 to 10.0 $\mu \mathrm{m}$, while whereas MFG $<1.0 \mu \mathrm{m}$ and $>10.0 \mu \mathrm{m}$ were rare (Figure 1). Previous research reported an effect of diet on small $\left(\mathrm{D}_{[4,3]}\right.$ of $\left.3.44 \mu \mathrm{m}\right)$ and large MFG $\left(\mathrm{D}_{[4,3]}\right.$ of $4.53 \mu \mathrm{m}$; Couvreur et al., 2007). For instance, extruded linseed supplementation (i.e., providing additional linolenic acid) to dairy cows decreased $\mathrm{D}_{[3,2]}(3.66 \mu \mathrm{m})$ and

Table 1. Effects of a 6-d Ca-CLA supplementation to mid-lactation Holstein cows on lactation performance and milk composition

\begin{tabular}{|c|c|c|c|c|c|c|}
\hline \multirow[b]{2}{*}{ Item } & \multicolumn{2}{|c|}{ Treatment $^{1}$} & \multirow[b]{2}{*}{ SEM } & \multicolumn{3}{|c|}{$P$-value } \\
\hline & Control & CLA & & Treatment & Time & Treatment $\times$ time \\
\hline DMI, kg/d & 16.53 & 15.98 & 0.39 & 0.37 & 0.60 & 0.71 \\
\hline Milk yield, $\mathrm{kg} / \mathrm{d}$ & 28.76 & 28.03 & 0.37 & 0.19 & 0.22 & 0.12 \\
\hline Milk protein, \% & 3.35 & 3.17 & 0.09 & 0.21 & 0.56 & 0.51 \\
\hline Milk protein yield, $\mathrm{g} / \mathrm{d}$ & 966.45 & 887.15 & 31.39 & 0.10 & 0.72 & 0.23 \\
\hline Milk fat, $\%$ & 3.46 & 2.52 & 0.14 & $<0.01$ & 0.02 & $<0.01$ \\
\hline Milk fat yield, g/d & 998.76 & 702.51 & 42.84 & $<0.01$ & 0.11 & $<0.01$ \\
\hline Milk lactose, \% & 4.94 & 4.82 & 0.05 & 0.15 & 0.18 & 0.53 \\
\hline Milk lactose yield, $\mathrm{g} / \mathrm{d}$ & $1,421.72$ & $1,353.21$ & 30.19 & 0.14 & 0.11 & 0.22 \\
\hline TS yield, g/d & $3,606.85$ & $3,122.36$ & 68.04 & $<0.01$ & 0.02 & 0.22 \\
\hline $\mathrm{D}_{[4,3]}, \mu \mathrm{m}$ & 4.12 & 3.73 & 0.13 & 0.07 & 0.08 & 0.50 \\
\hline $\mathrm{D}_{[3,2]}^{[4,2]}, \mu \mathrm{m}$ & 3.45 & 3.02 & 0.11 & 0.02 & 0.54 & 0.02 \\
\hline
\end{tabular}

${ }^{1} \mathrm{n}=6$ cows each in the control and CLA groups.

${ }^{2}$ Volume-related equivalent diameter.

${ }^{3}$ Surface area-related equivalent diameter. 
increased $\mathrm{D}_{[4,3]}(4.73 \mu \mathrm{m}) \mathrm{MFG}$ (Lopez et al., 2008). In $\left.=0.07\right) \mathrm{MFG}$, suggesting a negative association among the present study, compared with the control diet, feeding CLA led to lower $\mathrm{D}_{[3,2]}(3.45$ vs. $3.02 \mu \mathrm{m}, P=0.02$, exogenous CLA, milk fat content, and MFG size.

Table 1) and tended to lower $\mathrm{D}_{[4,3]}(4.12$ vs. $3.73 \mu \mathrm{m}, P$ researchers have reported MFD specifically with the
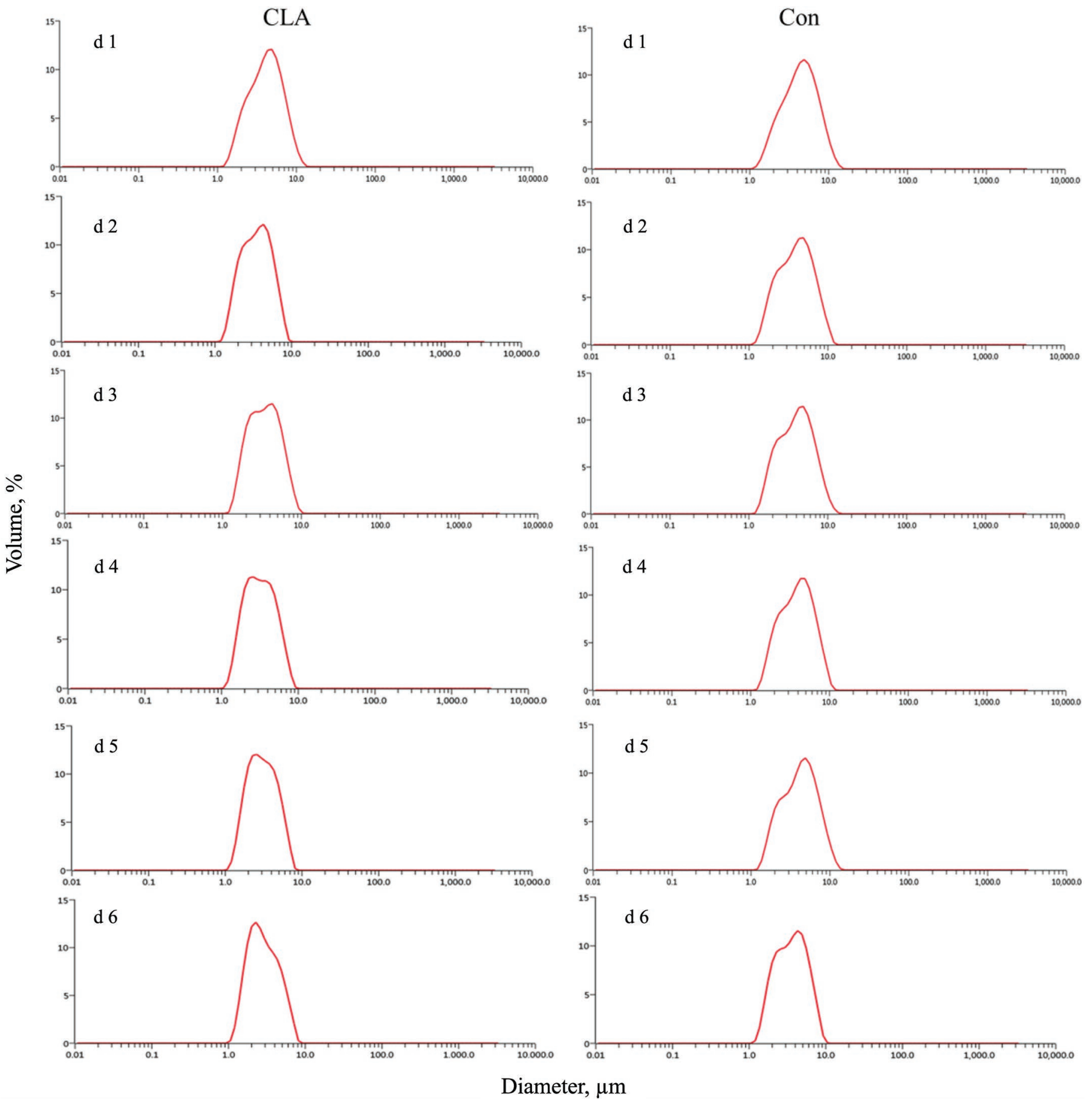

Figure 1. Representative examples of milk fat globule size distribution between the control (control basal diet) and CLA (control plus Caprotected CLA at $15 \mathrm{~g} / \mathrm{kg}$ of DM) groups from d 1 to 6 of the experiment. The particle size distribution graph was generated by Mastersizer 3000 software (Malvern Instruments Ltd., Malvern, UK). 
Table 2. Effects of a 6-d Ca-CLA supplementation to mid-lactation Holstein cows on the size distribution of fat globule particles (\% of total fat globules)

\begin{tabular}{|c|c|c|c|c|c|c|}
\hline \multirow{2}{*}{$\begin{array}{l}\text { Size, } \\
\mu \mathrm{m}\end{array}$} & \multicolumn{2}{|c|}{ Treatment $^{1}$} & \multirow[b]{2}{*}{ SEM } & \multicolumn{3}{|c|}{$P$-value } \\
\hline & Control & CLA & & Treatment & Time & Treatment $\times$ time \\
\hline 1.19 & 0.10 & 0.58 & 0.10 & 0.01 & 0.31 & 0.21 \\
\hline 1.36 & 1.00 & 2.03 & 0.21 & $<0.01$ & 0.12 & 0.09 \\
\hline 1.54 & 2.84 & 4.17 & 0.29 & 0.01 & 0.07 & 0.07 \\
\hline 1.75 & 5.08 & 6.41 & 0.38 & 0.03 & 0.05 & 0.07 \\
\hline 1.99 & 7.07 & 8.41 & 0.48 & 0.07 & 0.02 & 0.04 \\
\hline 2.27 & 8.41 & 9.17 & 0.49 & 0.29 & 0.05 & 0.10 \\
\hline 2.58 & 9.17 & 9.60 & 0.46 & 0.52 & 0.06 & 0.14 \\
\hline 2.93 & 9.80 & 9.88 & 0.41 & 0.89 & 0.05 & 0.25 \\
\hline 3.33 & 10.68 & 10.32 & 0.39 & 0.53 & 0.01 & 0.58 \\
\hline 3.78 & 11.73 & 10.81 & 0.39 & 0.12 & 0.01 & 0.47 \\
\hline 4.29 & 12.37 & 10.88 & 0.38 & 0.02 & 0.07 & 0.13 \\
\hline 4.88 & 11.96 & 10.11 & 0.41 & 0.01 & 0.07 & 0.11 \\
\hline 5.55 & 10.39 & 8.51 & 0.49 & 0.02 & 0.12 & 0.12 \\
\hline 6.30 & 8.11 & 6.46 & 0.59 & 0.07 & 0.11 & 0.14 \\
\hline 7.16 & 5.61 & 4.36 & 0.64 & 0.19 & 0.06 & 0.14 \\
\hline 8.14 & 3.22 & 2.49 & 0.60 & 0.41 & 0.01 & 0.11 \\
\hline 9.24 & 1.50 & 1.25 & 0.45 & 0.70 & 0.01 & 0.23 \\
\hline
\end{tabular}

${ }^{1} \mathrm{n}=6$ cows each in the control and CLA groups.

trans-10, cis-12 isomer. For example, Baumgard et al. (2001) infused $0.0,3.5,7.0$, and $14.0 \mathrm{~g} / \mathrm{d}$ of trans10,cis-12 CLA during a 5-d period (Baumgard et al., 2001), and Loor and Herbein (2003) infused $15 \mathrm{~g} / \mathrm{d}$ for $2 \mathrm{~d}$ in cows fed high-oleic or high-linoleic oil. In the present study, CLA was the only source of PUFA and the amount fed was beyond the expected physiological levels that could reach the small intestine. Thus, future studies using other PUFA such as linoleic acid or physiological doses of CLA could provide more in-depth understanding of the mechanisms regulating MFG size and associations with milk fat content.

Feeding CLA led to greater percentage of small MFG (size from 1.19 to $1.99 \mu \mathrm{m}$ ) and lower percentage of large MFG (size from 4.29 to $6.30 \mu \mathrm{m} ; P<0.05$ or 0.05 $\leq P \leq 0.10$, Table 2 ). Other MFG were not affected by feeding CLA $(P>0.01)$. The decrease in the average diameter of MFG following CLA supplementation was associated with an increase in small MFG and a decrease in large MFG (Table 2). Therefore, the decrease in the size of fat globule particles due to CLA was accompanied by changes in the size distribution of MFG.

Bovine mammary epithelial cells synthesize lipid droplets (LD) and secrete them as MFG into the milk, supporting the view that they serve as an indicator of mammary synthesis capacity for milk fat (Altenhofer et al., 2015). To our knowledge, this report is the first to document changes in MFG size during CLA-induced MFD. The data suggest that an increase in small fat globules along with a decrease in large fat globules was due to reduced milk fat synthesis capacity of the mammary gland during CLA-induced MFD. Molecular mechanisms linking CLA and MFD in ruminants have mainly been focused on the downregulation of mRNA abundance of key de novo fatty acid synthesis enzymes (Gervais et al., 2009; Han et al., 2012; Harvatine et al., 2018). Although the precise mechanisms controlling the size of MFG are unclear, MFG size has been suggested to be determined by the size of $\mathrm{LD}$ produced before and during secretion (Argov-Argaman, 2019). Thus, a co-regulatory mechanism involving intracellular triacylglycerol synthesized, membrane material availability, and LD fusion has been proposed to exist in the control of LD size (Argov-Argaman, 2019). Clearly, more studies are needed to more precisely understand the mechanisms involved in controlling LD and MFG size along with their secretion by the mammary gland.

\section{ACKNOWLEDGMENTS}

This research was jointly supported by National Key Research and Development Program of China (2016YFD0500503) and National Natural Science Foundation of China (U190410517). The authors have not stated any conflicts of interest.

\section{REFERENCES}

Altenhofer, C., W. Holzmüller, F. Wolfertstetter, D. Wolfschoon Ribeiro, U. Kulozik, M. W. Pfaffl, and E. Viturro. 2015. Temporal variation of milk fat globule diameter, fat and cholesterol content and milk epithelial cell gene expression in dairy cows. Int. J. Dairy Technol. 68:519-526. https://doi.org/10.1111/1471-0307.12220.

Argov, N., D. G. Lemay, and J. B. German. 2008. Milk fat globule structure \& function; nanoscience comes to milk production. Trends Food Sci. Technol. 19:617-623. https://doi.org/10.1016/j .tifs.2008.07.006. 
Argov-Argaman, N. 2019. Symposium review: Milk fat globule size: Practical implications and metabolic regulation. J. Dairy Sci. 102:2783-2795. https://doi.org/10.3168/jds.2018-15240.

Argov-Argaman, N., R. Mesilati-Stahy, Y. Magen, and U. Moallem. 2014. Elevated concentrate-to-forage ratio in dairy cow rations is associated with a shift in the diameter of milk fat globules and remodeling of their membranes. J. Dairy Sci. 97:6286-6295. https: //doi.org/10.3168/jds.2014-8174.

Argov-Argaman, N., K. Mida, B. C. Cohen, M. Visker, and K. Hettinga. 2013. Milk fat content and DGAT1 genotype determine lipid composition of the milk fat globule membrane. PLoS One 8:e68707. https://doi.org/10.1371/journal.pone.0068707.

Bauman, D. E., and J. M. Griinari. 2000. Regulation and nutritional manipulation of milk fat. Low-fat milk syndrome. Adv. Exp. Med. Biol. 480:209-216. https://doi.org/10.1007/0-306-46832-8_26.

Bauman, D. E., and J. M. Griinari. 2003. Nutritional regulation of milk fat synthesis. Annu. Rev. Nutr. 23:203-227. https://doi.org/ 10.1146/annurev.nutr.23.011702.073408.

Bauman, D. E., J. W. Perfield II, K. J. Harvatine, and L. H. Baumgard. 2008. Regulation of fat synthesis by conjugated linoleic acid: Lactation and the ruminant model. J. Nutr. 138:403-409. https:// doi.org/10.1093/jn/138.2.403.

Baumgard, L. H., B. A. Corl, D. A. Dwyer, A. Saebo, and D. E. Bauman. 2000. Identification of the conjugated linoleic acid isomer that inhibits milk fat synthesis. Am. J. Physiol. Regul. Integr. Comp. Physiol. 278:R179-R184. https://doi.org/10.1152/ajpregu 2000.278.1.R179.

Baumgard, L. H., J. K. Sangster, and D. E. Bauman. 2001. Milk fat synthesis in dairy cows is progressively reduced by increasing supplemental amounts of trans-10, cis-12 conjugated linoleic acid (CLA). J. Nutr. 131:1764-1769. https://doi.org/10.1093/jn/131.6 1764 .

Bichi, E., G. Hervás, P. G. Toral, J. J. Loor, and P. Frutos. 2013. Milk fat depression induced by dietary marine algae in dairy ewes: Persistency of milk fatty acid composition and animal performance responses. J. Dairy Sci. 96:524-532. https://doi.org/10.3168/jds $.2012-5875$.

Bionaz, M., and J. J. Loor. 2008. Gene networks driving bovine milk fat synthesis during the lactation cycle. BMC Genomics 9:366. https://doi.org/10.1186/1471-2164-9-366.

Couvreur, S., C. Hurtaud, P. G. Marnet, P. Faverdin, and J. L. Peyraud. 2007. Composition of milk fat from cows selected for milk fat globule size and offered either fresh pasture or a corn silage-based diet. J. Dairy Sci. 90:392-403. https://doi.org/10.3168/jds.S0022 -0302(07)72640-1.

Gervais, R., J. W. McFadden, A. J. Lengi, B. A. Corl, and P. Y. Chouinard. 2009. Effects of intravenous infusion of trans-10, cis-12 18:2 on mammary lipid metabolism in lactating dairy cows. J. Dairy Sci. 92:5167-5177. https://doi.org/10.3168/jds.2009-2281.
Han, L. Q., K. Pang, H. J. Li, S. B. Zhu, L. F. Wang, Y. B. Wang, G. Q. Yang, and G. Y. Yang. 2012. Conjugated linoleic acid-induced milk fat reduction associated with depressed expression of lipogenic genes in lactating Holstein mammary glands. Genet. Mol Res. 11:4754-4764. https://doi.org/10.4238/2012.September.17.2.

Harvatine, K. J., Y. R. Boisclair, and D. E. Bauman. 2018. Timedependent effect of trans-10, cis-12 conjugated linoleic acid on gene expression of lipogenic enzymes and regulators in mammary tissue of dairy cows. J. Dairy Sci. 101:7585-7592. https://doi.org/ 10.3168/jds.2017-13935.

Loor, J. J., A. B. Bandara, and J. H. Herbein. 2002. Characterization of 18:1 and 18:2 isomers produced during microbial biohydrogenation of unsaturated fatty acids from canola and soya bean oil in the rumen of lactating cows. J. Anim. Physiol. Anim. Nutr. (Berl.) 86:422-432. https://doi.org/10.1046/j.1439-0396.2002.00403.x.

Loor, J. J., and J. H. Herbein. 2003. Reduced fatty acid synthesis and desaturation due to exogenous trans10, cis12-CLA in cows fed oleic or linoleic oil. J. Dairy Sci. 86:1354-1369. https://doi.org/10 .3168/jds.S0022-0302(03)73720-5.

Lopez, C., V. Briard-Bion, O. Menard, F. Rousseau, P. Pradel, and J. M. Besle. 2008. Phospholipid, sphingolipid, and fatty acid compositions of the milk fat globule membrane are modified by diet. J. Agric. Food Chem. 56:5226-5236. https://doi.org/10.1021/ jf7036104.

Mesilati-Stahy, R., and N. Argov-Argaman. 2014. The relationship between size and lipid composition of the bovine milk fat globule is modulated by lactation stage. Food Chem. 145:562-570. https:/ /doi.org/10.1016/j.foodchem.2013.08.077.

Michalski, M. C., V. Briard, F. Michel, F. Tasson, and P. Poulain. 2005. Size distribution of fat globules in human colostrum, breast milk, and infant formula. J. Dairy Sci. 88:1927-1940. https://doi .org/10.3168/jds.S0022-0302(05)72868-X.

NRC. 2001. Nutrient Requirements of Dairy Cattle. 7th rev. ed. Natl. Acad. Press, Washington, DC.

Perfield, J. W. II, G. Bernal-Santos, T. R. Overton, and D. E. Bauman. 2002. Effects of dietary supplementation of rumen-protected conjugated linoleic acid in dairy cows during established lactation. J. Dairy Sci. 85:2609-2617. https://doi.org/10.3168/jds.S0022 -0302(02)74346-4

Viswanadha, S., J. G. Giesy, T. W. Hanson, and M. A. McGuire. 2003. Dose response of milk fat to intravenous administration of the trans-10,cis-12 isomer of conjugated linoleic acid. J. Dairy Sci. 86:3229-3236. https://doi.org/10.3168/jds.S0022-0302(03)73926 -5 .

\section{ORCIDS}

J. J. Loor @ https://orcid.org/0000-0003-1586-4365 